\title{
INTERACTION OF TETRACYCLINE WITH PROTEIN SYNTHESIZING SYSTEM OF STREPTOMYCES AUREOFACIENS
}

\author{
K. Mikulík, J. Karnetová, N. Quyen, \\ M. Blumauerová, I. Komersová and Z. VANĚK \\ Institute of Microbiology, Czechoslovak Academy of Sciences, \\ Prague, Czechoslovakia
}

(Received for publication April 13, 1971)

\begin{abstract}
The interaction between protein synthesis and production of tetracycline in Streptomyces aureofaciens was studied. It has been shown that the amount of tetracycline bound to ribosomes rapidly rises, as compared with the production of the drug. The accumulation of tetracycline in the cultivation medium results in the formation of tetracycline-ribosome aggregates. The highest level of binding was equivalent to 320 molecules of tetracycline per ribosome. The results obtained with the $\mathrm{S} 30$ fraction, containing endogenous mRNA suggest that protein-synthesizing system of tetracycline-producing microorganisms is more resistant to the antibiotic effect than similar systems isolated from drug-sensitive bacteria. Tetracycline itself can have a regulatory function in the metabolism of producing cells. Accumulation of tetracycline during growth may lead to limitation of protein synthesis and enzyme systems involved in the machinery of secondary metabolite biosynthesis.
\end{abstract}

The relationship between antibiotic synthesis and other metabolic processes of the producing cell has been the subject of numerous discussions. One approach to this problem is to correlate the formation of the antibiotics with the protein synthesizing machinery of the producing microorganism. As an experimental model we used Streptomyces aureofaciens which synthesizes a broad spectrum of metabolites, including antibiotics such as tetracycline and chlortetracycline.

This group of drugs interacts with a wide variety of reactions, involving respiration $^{1,2)}$ synthesis $^{3 \sim 6)}$ and activities of enzymes ${ }^{7 \sim 13)}$.

During the past few years there have been a number of reports about the inhibitory effect of tetracyclines on protein synthesis ; GuRgo et al. ${ }^{14)}$ and CundLIFFE ${ }^{15)}$ have reported that the addition of tetracycline to Escherichia coli cells caused an inhibition of polysome formation and an accumulation of free $30 \mathrm{~S}$ and $50 \mathrm{~S}$ ribosomal subunits. Data from several laboratories have indicated that tetracyclines prevent the binding of aminoacyl-tRNA to the aminoacyl acceptor site of ribosomes ${ }^{16 \sim 19)}$. However, higher concentrations of tetracycline inhibit also the release of deacylated tRNA from ribosomes ${ }^{20,21)}$.

The purpose of the experiments described in this communication was to study the interaction of tetracycline with protein synthesizing machinery of S.aureofaciens, which produces under laboratory condition about 200 times more of the drug than the 
amount required for total inhibition of growth of sensitive bacterial cells.

\section{Material and Methods}

Streptomyces aureofaciens, tetracycline-producing strain (84/25) was obtained from the Research Institute of Antibiotics and Biotransformations (Prague). The cultures were grown at $28^{\circ} \mathrm{C}$ in $500-\mathrm{ml}$ flasks containing $60 \mathrm{ml} \mathrm{media}{ }^{22)}$. The cells were harvested at different stages of growth and washed by suspension in a cold buffer containing $10 \mathrm{mM}$ Tris- $\mathrm{HCl} \mathrm{pH} 7.5,10 \mathrm{~mm}$ magnesium acetate, $60 \mathrm{~mm} \mathrm{KCl}$ and $6 \mathrm{~mm}$ 2-mercaptoethanol (TCMK).

In vivo ${ }^{14} \mathrm{C}$-leucine incorporation into proteins

Radioactive $\mathrm{U}^{14} \mathrm{C}$-leucine, specific activity $83 \mathrm{mC} / \mathrm{mMol}$ was added to the cultures of S. aureofaciens in an amount of $20 \mu \mathrm{C} / 60 \mathrm{ml}$ medium. In experiments following the effect of tetracycline on ${ }^{14} \mathrm{C}$-leucine incorporation, $50 \sim 1,000 \mu \mathrm{g} / \mathrm{ml}$ tetracycline was supplied at 4 hours of cultivation. One $\mathrm{ml}$ samples were withdrawn at different intervals of growth and poured into $2 \mathrm{ml}$ of $10 \%$ TCA. Chilled samples were filtered and washed on membrane filters. Radioactivity was measured on a Biospan Nuclear Chicago Counter.

In vivo ${ }^{14} \mathrm{C}$-thymine incorporation into DNA

Radioactive ${ }^{14} \mathrm{C}$-thymine (specific activity $50 \mathrm{mC} / \mathrm{mMol}$ ), was added at the beginning of the cultivation of S.aureofaciens in an amount of $20 \mu \mathrm{C} / 60 \mathrm{ml}$ medium. One $\mathrm{ml}$ aliquots were poured into $2 \mathrm{ml}$ of ice cold $5 \%$ TCA, filtered and washed on membrane filters. Radioactivity was measured as in the experiments with radioactive amino acid.

Preparation of ribosomes and ribosomal subunits

Isolation of ribosomes from alumina-ground cells is described elsewhere ${ }^{23)}$. The ribosomal pellet was washed twice with TCMK buffer $\mathrm{pH} 7.6$, and the ribosomes purified by centrifugation through $30 \%$ sucrose in the same buffer. The purification procedure was repeated twice. The ribosomes were dissociated into subunits by dialysis against TCMK buffer containing $0.1 \mathrm{mM}$ magnesium acetate. The ribosomal subunits were layered over $28 \mathrm{ml} 10 \sim 30 \%$ sucrose gradient and centrifuged in an SW 25.1 rotor for $151 / 2$ hours at 19,600 r.p.m. on a Spinco model L2-65 B centrifuge. Separated subunits from 3 tubes were combined and centrifuged for 5 hours at 48,000 r.p.m. in a 50.1 rotor. The separation procedure was repeated twice.

Gel filtration of ribosomal aggregates

Ribosomes, $3.75 \mathrm{mg}$, were incubated in a mixture containing $10 \mathrm{~mm}$ Tris- $\mathrm{HCl}$ buffer $\mathrm{pH} 7.5,10 \mathrm{mM} \mathrm{MgCl}_{2}, 30 \mathrm{mM} \mathrm{NH}_{4} \mathrm{Cl}, 6 \mathrm{~mm}$ 2-mercaptoethanol and $1 \mathrm{~mm}{ }^{3} \mathrm{H}$-tetracycline $(1 \mu \mathrm{C})$. After 90 -minute incubation at $30^{\circ} \mathrm{C}$, the mixture was centrifuged at $105,000 \times \mathrm{g}$ for 30 minutes, the supernatant discarded and the ribosomal aggregates washed with $10 \mathrm{ml}$ of the above buffer to remove free tetracycline. The resulting sediment was suspended in $1 \mathrm{ml}$ of buffer and passed through a $2 \times 50 \mathrm{~cm}$ Sephadex G 50 column.

Aminoacyl synthetase preparation

Aminoacyl synthetase activity was estimated in a partially purified $105,000 \times g$ supernatant fraction $^{24)}$. The supernatant fraction was stirred and $0.2 \mathrm{ml}$ of $5 \%$ streptomycin sulfate solution slowly added. After 15 minutes of stirring, the precipitated material was removed by centrifugation at $10,000 \times g$. The sediment was removed and the supernatant adjusted to $\mathrm{pH} 5.2$ with $0.1 \mathrm{~N} \mathrm{HCl}$. The mixture was centrifuged at $10,000 \times g$ for 10 minutes. The supernatant was discarded and the sediment suspended in $0.1 \mathrm{M}$ Tris- $\mathrm{HCl}$ buffer $(\mathrm{pH}$ 7.6) containing $6 \mathrm{mM}$ dithiothreitol. After 8-hour dialysis against the same buffer the solution was centrifuged at $15,000 \times g$ for 10 minutes. The supernatant solution was mixed $1: 1$ with glycerol and stored until use at $-20^{\circ} \mathrm{C}$. This solution was used as a source of aminoacyl synthetase activity.

Cell-free amino acid incorporating system

The activity of the S 30 fraction and the effect of tetracycline were assayed using an in vitro ${ }^{14} \mathrm{C}$-valine-incorporating system of MatthaeI and NirenberG ${ }^{24)}$. The specific activity 
of $\mathrm{L}^{-14} \mathrm{C}$-valine (New England Nuclear Corp.) was $50 \mathrm{mC} / \mathrm{mMol}$. The reaction mixtures were incubated at $37^{\circ} \mathrm{C}$ for 25 minutes and then treated with $3 \mathrm{ml}$ of $10 \%$ TCA. The samples were heated in a water bath for 20 minutes at $90^{\circ} \mathrm{C}$, then chilled in ice and filtered under suction through a membrane filter. The radioactivity of the dried filters was measured.

Sedimentation velocity analysis

This was done in a Spinco model E analytical ultracentrifuge. The sedimentation was studied at 37,020 r.p.m. and $20^{\circ} \mathrm{C}$. Bar angle $60^{\circ}$.

Preparation of ribosomal proteins

Ribosomal proteins were prepared from purified ribosomes by the LiCl-urea method of TRAUB and NomUra ${ }^{25)}$.

Electrophoresis

Polyacrylamide disc electrophoresis of ribosomal proteins was carried out by the method of Gesteland and Staenelin ${ }^{26)}$. The tube size was $0.6 \times 7.0 \mathrm{~cm}$. The samples were added on top of the upper gel, along with $1 \mu$ l of $0.1 \%$ pyronine Y (Fischer, P 388). Electrophoresis was done in the cold, for about 3 hours at $5 \mathrm{~mA} /$ tube. The gels were stained with amidoblack $10 \mathrm{~B}$ (Merck) used as a $0.5 \%$ solution in $7.5 \%$ acetic acid.

\section{Results and Discussion}

The first question studied was whether tetracycline can pass through the cell wall of S. aureofaciens and interfere with two essential steps of cell metabolism, i.e. protein synthesis and synthesis of DNA. Fig. 1 shows the course of synthesis of DNA (measured as incorporation of ${ }^{14} \mathrm{C}$-thymine into $\mathrm{DNA}$ ), incorporation of ${ }^{14} \mathrm{G}$-leucine into proteins and production of tetracycline. Incorporation of ${ }^{14} \mathrm{C}$-thymine as well as ${ }^{14} \mathrm{C}$-leucine increased up to 12 hours of cultivation, while the concentration of tetracycline in the fermentation medium remained relatively low $(50 \mu \mathrm{g} / \mathrm{ml})$. The later increase in tetracycline production was accompanied by a decrease of radioactivity of both DNA and

Fig. 1. The course of ${ }^{14} \mathrm{C}$-leucine incorporation into the proteins, the ${ }^{14} \mathrm{C}-$ thymine incorporation into DNA and production of tetracycline. For experimental details, see Material and Methods.

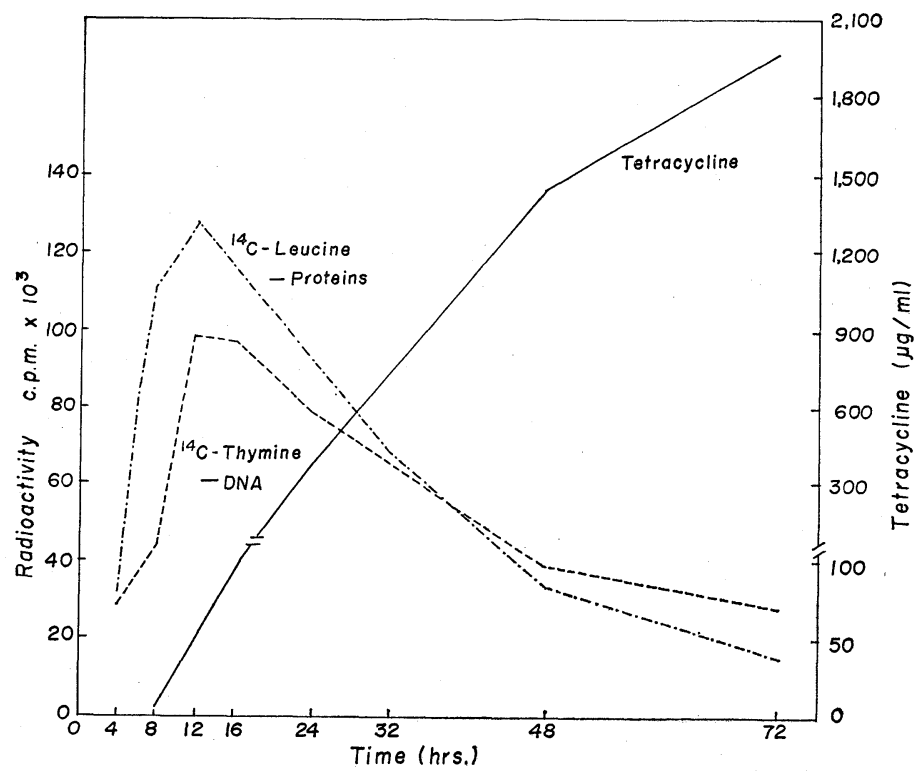


Fig. 2. The effect of addition of tetracycline at different intervals of growth of $S$. aureofaciens on ${ }^{14} \mathrm{C}$-leucine and ${ }^{14} \mathrm{C}$-thymine incorporation and on production of the antibiotic.

A : the course of ${ }^{14} \mathrm{C}$-leucine incorporation into proteins after addition of $500 \mu \mathrm{g} / \mathrm{m} 1$ tetracycline at 16 hours of cultivation

$\mathrm{B}$ : the course of tetracycline production before and after addition of $500 \mu \mathrm{g} / \mathrm{ml}$ tetracycline at 16 hours of cultivation

$\mathrm{C}:$ the course of ${ }^{14} \mathrm{C}$-leucine incorporation after addition of $500 \mu \mathrm{g} / \mathrm{ml}$ tetracycline to 4 -hour culture

$D$ : the course of ${ }^{14} \mathrm{C}$-thymine incorporation under the same experimental condition

$\mathrm{E}:$ the level of tetracycline after addition of $500 \mu \mathrm{g} / \mathrm{m} 1$ tetracycline to 4 -hour culture.

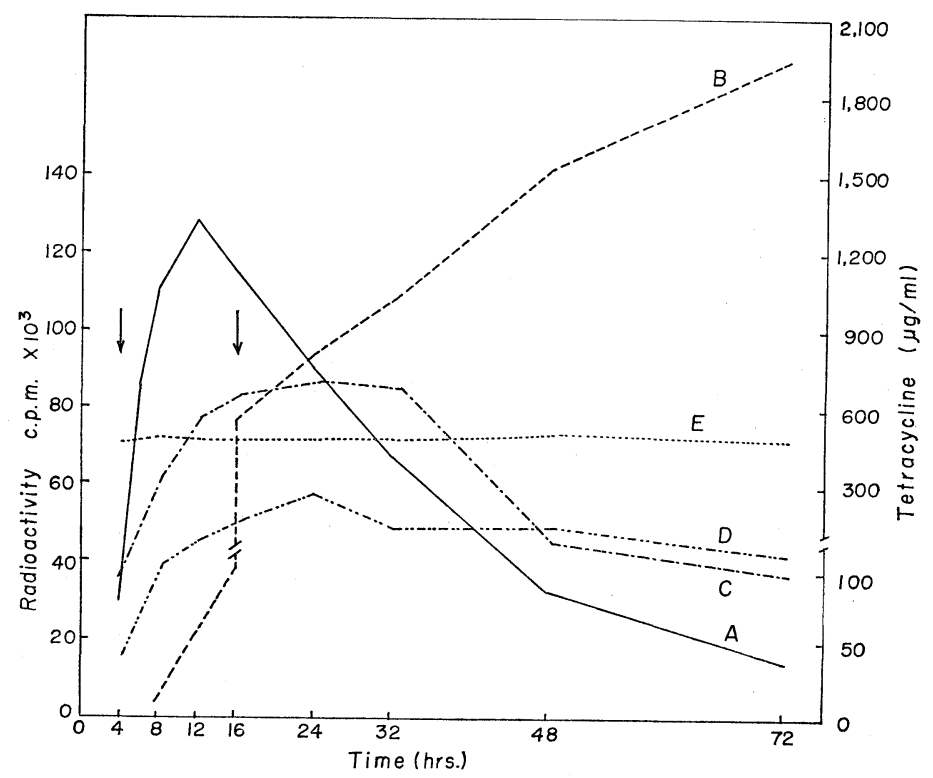

Fig. 3. Distribution of tetracycline among the subcellular fraction. Ribosomes and S-100 fraction were prepared as described in the Material and Methods section.

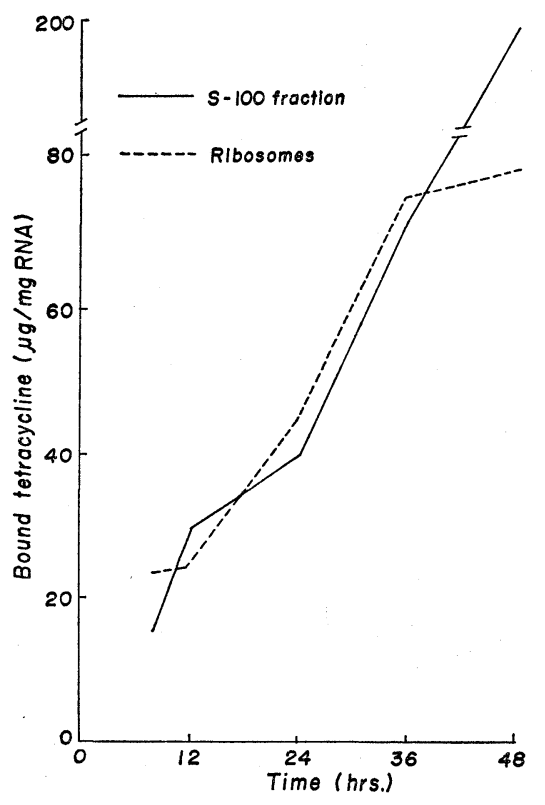

proteins. At 72 hours of cultivation, the accumulation of tetracycline was about $2,000 \mu \mathrm{g} / \mathrm{ml}$.

The effect of tetracycline on cultures at different stages of growth was then studied. The addition of $500 \mu \mathrm{g} / \mathrm{ml}$ tetracycline to a 4-hour culture (Fig. 2) resulted in a $37 \%$ inhibition of ${ }^{14} \mathrm{C}$-leucine incorporation into proteins, a $45 \%$ inhibition of ${ }^{1} \mathrm{C}$-thymine incorporation to DNA and a shift of the maximum incorporation to about 12 hours. The production of tetracycline was totally inhibited.

When the drug was added to a 16-hour culture under the same experimental condition, the synthesis of tetracycline was not affected. These results indicate that tetracycline interferes with the synthesis of specific enzymes which are needed for the biosynthesis of the antibiotic rather than with their activities.

Intracellular localization of tetracycline, sedimentation and electrophoretical pattern of the ribosomes 
Fig. 4. Sedimentation profile of crude ribosomal preparations isolated from 8,12 , 24,48 and 72 hours of cultivation of the tetracycline producing strain.

Each sample contains $2,5 \mathrm{mg}$ proteins. Centrifugations were performed in a Spinco Model E analytical ultracentrifuge at $37,020 \mathrm{r} . \mathrm{p} . \mathrm{m}$. at $20^{\circ} \mathrm{C}$, using a $60^{\circ}$ bar angle.

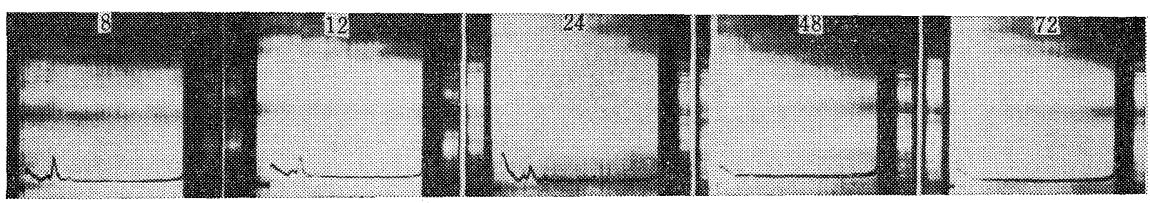

Fig. 5. Electrophoretic pattern of ribosomal proteins isolated from ribosomes of 8,12 and 24-hour cultures of $S$. aureofaciens.

Electrophoresis was carried out at $\mathrm{pH} \mathrm{4,5}$. in the cold at $5 \mathrm{~mA} /$ column.

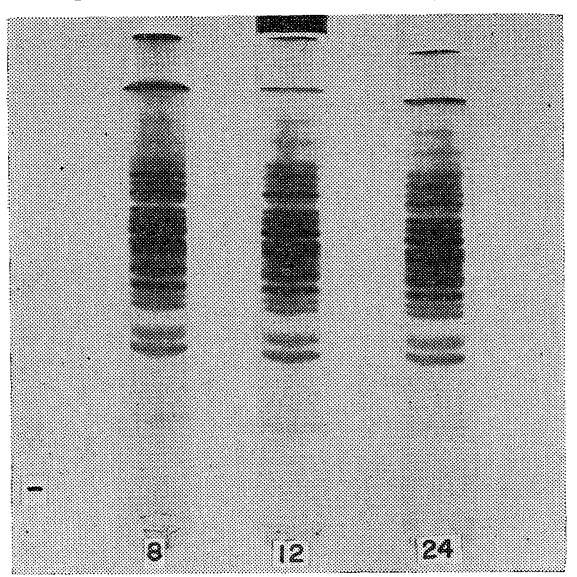

Further experiments were performed in order to ascertain whether intracellular accumulation of tetracycline during the growth of a tetracyclineproducing strain of $S$. aureofaciens is accompanied by changes in the sedimentation properties of ribosomes. The results presented in Fig. 3 indicate that the amount of tetracycline bound to subcellular fractions rose rapidly at about 24 hours of cultivation, comparable with production of the antibiotic (Fig. 1). The sedimentation profile of the ribosomes remained consistent up to 24 hours of growth; i.e. up to the time when the concentration of tetracycline in the cultivation medium did not exceed $500 \mu \mathrm{g} / \mathrm{ml}$ (Fig. 4). Moreover, the electrophoretic patterns of ribosomal proteins isolated from ribosomes of 8,12 and 24-hour cultures of the producing strain also remained unaltered (Fig. 5). The preparation isolated from 48 and 72-hour cultures contain ribosomal aggregates which sediment rapidly. Electronoptic evidence for the formation of such ribosomal aggregates in the presence of higher concentrations of chlortetracycline $(1 \mathrm{~mm})$ has been reported in a previous paper ${ }^{27)}$.

Binding of tetracycline to ribosomes and ribosomal subunits

It has been reported that tetracycline binds to $70 \mathrm{~S}$ ribosomes ${ }^{28 \sim 30}$ ) and ribosomal usbunits. The amount of tetracycline bound to $30 \mathrm{~S}$ subunits is considerably greater than to $50 \mathrm{~S}$ subunits ${ }^{31)}$. This was confirmed in our experiments with the ribosomes of S. aureofaciens. Five hundreds $\mu \mathrm{g} / \mathrm{ml}$ of ${ }^{3} \mathrm{H}$-tetracycline $(20 \mu \mathrm{C})$ were added to a 10-hour culture. After 2 hours of cultivation at $28^{\circ} \mathrm{C}$, the culture was chilled, washed twice with TCMK buffer ( $\mathrm{pH}$ 7.5). The ribosomes isolated were dialyzed against TCMK buffer containing either $10 \mathrm{~mm}$ or $0.1 \mathrm{~mm}$ magnesium acetate. Ribosomes and ribosomal subunits were fractionated into sucrose density gradients. The results presented as Fig. 6 show that radioactivity of ${ }^{3} \mathrm{H}$-tetracycline was associated with $70 \mathrm{~S}$ and $100 \mathrm{~S}$ dimers. In experiments using $0.1 \mathrm{mM} \mathrm{Mg}^{2+}$ the main radioactivity from tetracycline was associated with the $30 \mathrm{~S}$ subunits. A small but significant radioactivity is associated with the $50 \mathrm{~S}$ particles. Considerable radioactivity was found with the ribosomal aggregates sedimenting at the bottom of the centrifugation tubes. These agregates are stable when treated with trypsin or pancreatic ribonuclease. The 
Fig. 6. Binding of ${ }^{3} \mathrm{H}$-tetracycline to ribosomes and ribosomal subunits of the tetracycline-producing strain of S. aureofaciens.

Cells of 10 -hour cultures were treated for 2 hours with ${ }^{3} \mathrm{H}$-tetracycline $500 \mu \mathrm{g} / \mathrm{ml}$ $(20 \mu \mathrm{C}) .20 \mathrm{~A}_{260}$ units of ribosomal subunits (B) and $19 \mathrm{~A}_{260}$ units of ribosomes (A) were layered on $10 \sim 30 \%$ sucrose gradients and centrifuged for $151 / 2$ hours at 19,600 r.p. $\mathrm{m}$. One $\mathrm{ml}$ fractions were collected. The sediment remaining at the bottom of the centrifugation tubes was suspended in $1 \mathrm{ml}$ of TCMK buffer $\mathrm{pH} 7.5$.
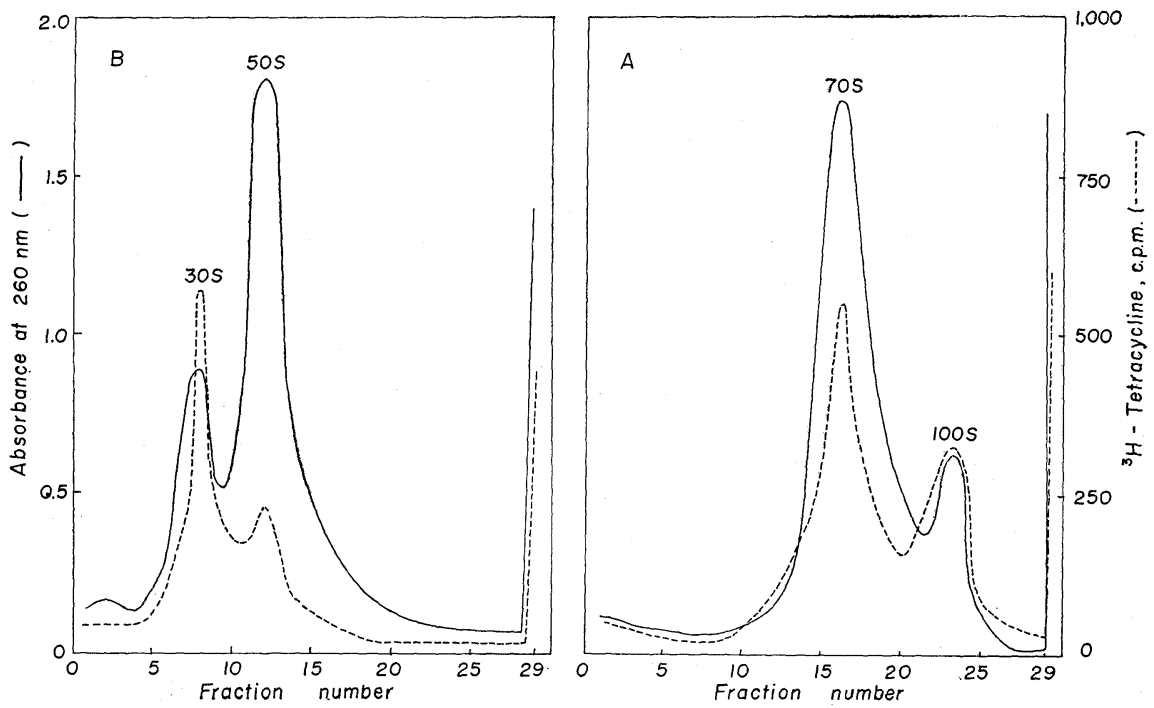

Fig. 7. Sephadex G 50 gel filtration of tetracycline-ribosome complex. washed complex was applied on a $2 \times 50 \mathrm{~cm}$ Sephadex G 50 column and eluted with $10 \mathrm{~mm}$ Tris-HCl buffer $\mathrm{pH} 7.5$, containing $10 \mathrm{mM} \mathrm{MgCl}_{2}, 30 \mathrm{mM} \mathrm{NH}_{4} \mathrm{Cl}$ and $6 \mathrm{~mm}$ 2-mercaptoethanol.

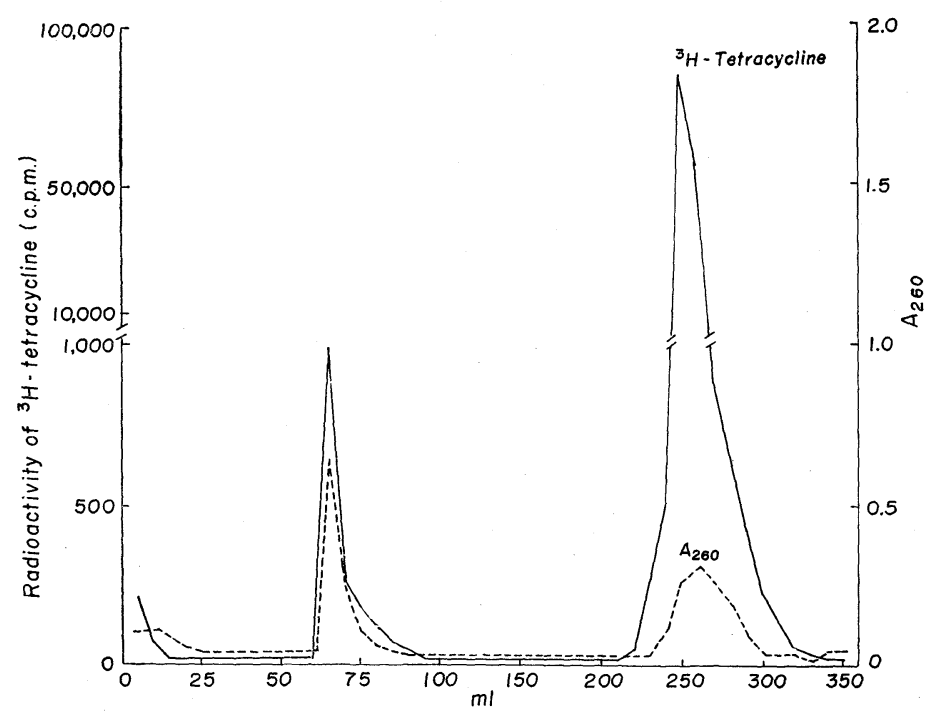

maximum level of binding observed was equivalent to 320 molecules of tetracycline per ribosome. This value was calculated from the absorbance and radioactivity of the $70 \mathrm{~S}$ peak fraction. The binding of tetracycline to the ribosomes of S.aureofaciens was largely reversible, like that reported for the ribosomes of Bacillus megatherium ${ }^{31}$.

Using ${ }^{3} \mathrm{H}$-tetracycline of high specific activity, it wsa possible to detect a level of irreversible binding. Fig. 7 shows an elution profile of the tetracycline-ribosome 
complex from a Sephadex G50 column. About $1 \%$ of the total radioactivity was connected with the ribosomes. It was concluded that about one molecule tetracycline was tightly bound to each ribosome.

Activation of amino acids and in vitro protein synthesis by the tetracyclineproducing strain of S. aureofaciens

Aminoacyl-tRNA synthetases fulfil two important roles in protein synthesis; i.e. activation of amino acids and translation of specific base sequences in the mRNA into amino acid specificity.

In order to obtain more detailed information about relationships between the initial steps of protein synthesis and the production of tetracycline, the charging of $E$. coli tRNAs with radioactive leucine, valine and alanine was estimated. These reactions were catalyzed by aminoacyl synthetases, isolated at different stages of growth of S.aureofaciens. The concentration of protein in these partially purified enzyme mixtures was adjusted to $1 \mathrm{mg} / \mathrm{ml}$. The maximum aminoacyl synthetase activity for all substrates studied was observed with preparations isolated from 12-hour cultures (Fig. 8). There exists a direct if not a proportional relationship between the depression of aminoacyl synthetase activity and the production of the antibiotic. Similar conclusions were reported by HošŤÁLEK et $a l .{ }^{32)}$ who studied interaction of individual enzymes of the tricarboxylic acid cycle and production of tetracycline by

Fig. 8. Activity of aminoacyl-tRNA synthetases at different intervals of growth and the production of tetracycline.

Partially purified preparations of aminoacyl synthetases (see Material and Methods) were incubated in a reaction mixture containing $0.1 \mathrm{M}$ Tris-HCl buffer $\mathrm{pH} 7.5,0.01 \mathrm{M} \mathrm{KCl}, 0.02 \mathrm{M}$ magnesium acetate, $0.005 \mathrm{M}$ ATP, $0.005 \mathrm{M}$ CTP, $8 \mathrm{~A}_{260}$ units of E.coli tRNA, $0.003 \mathrm{~m}$ mixture of unlabelled amino acid, plus $0.012 \mu$ moles of each of the ${ }^{14} \mathrm{C}$ amino acid tested. Incubation : 15 minutes at $37^{\circ} \mathrm{C}$. The reactions were stopped by adding $2 \mathrm{ml}$ of cold $10 \%$ TCA. The samples were filtered through a membrane filter, washed three times with $5 \mathrm{ml}$ of ice-cold 5\% TCA and radioactivity measured.

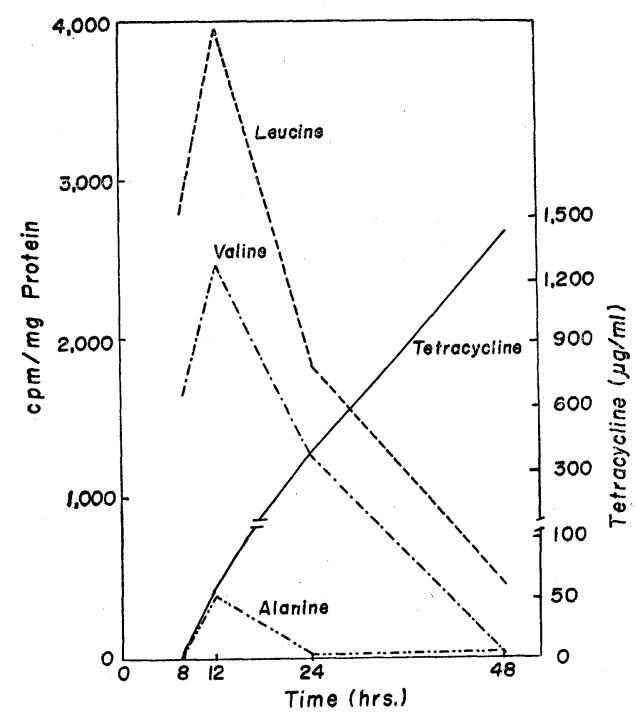

S. aureofaciens.

Next, we studied the effect of tetracycline on an in vitro protein-synthesizing system. Table 1 shows the composition of the system prepared from 10-hour cultures of S.aureofaciens. The incorporation of ${ }^{14} \mathrm{C}$-valine into proteins was proportional to the amount of $\mathrm{S} 30$ fraction added. The

Table 1. Characteristics of in vitro portein synthesis in Streptomyces aureofaciens directed by endogenous mRNA

\begin{tabular}{|c|c|}
\hline Incubation components & c. p. m. \\
\hline fraction $(1 \mathrm{mg} / \mathrm{ml})$ & 1,176 \\
\hline $\begin{array}{l}\text { mplete + nonpreincubated S } 30 \\
\text { fraction + DNAse }(5 \mu \mathrm{g} / \mathrm{ml})\end{array}$ & 1,128 \\
\hline $\begin{array}{l}\text { fomplete + nonpreincubated } \\
\text { fraction + RNAse ( } 5 \mu \mathrm{g} /\end{array}$ & 4 \\
\hline $\begin{array}{l}\text { ompl } \\
\text { frac }\end{array}$ & 110 \\
\hline \multicolumn{2}{|c|}{$\begin{array}{l}\text { The reaction mixtures contained in } \mu \text { mole } / \mathrm{ml}: \\
100 \text { Tris-HC1 } \mathrm{pH} 7.8,10 \text { magnesium acetate, } 50 \mathrm{KCl} \text {, } \\
62 \text {-mercaptoethano1, } 1 \text { ATP, } 0.03 \mathrm{GTP}, 5 \text { phospho- } \\
\text { enolpyruvate, } 20 \mu \mathrm{g} \text { PEP-kinase, } 0.05 \text { mixture of } \\
20 \text {-L-amino acids minus valine, } 0.018 \mathrm{~L} \text {-valine }(125 \\
\text { mC/mMo1) and S } 30 \text { fraction. Samples were in- } \\
\text { cubated at } 37^{\circ} \mathrm{C} \text { for } 25 \text { minutes, deproteinized with } \\
10 \% \text { TCA. Precipitates were washed } 3 \text { times with } \\
5 \% \text { TCA and counted on Biospan-Nuclear Chicago } \\
\text { counter. Background } 2 \text { imp/minute. }\end{array}$} \\
\hline
\end{tabular}


Fig. 9. The effect of tetracycline on the in vitro protein synthesis directed by endogenous mRNA.

The composition of reaction mixture was as described in Table 1 .

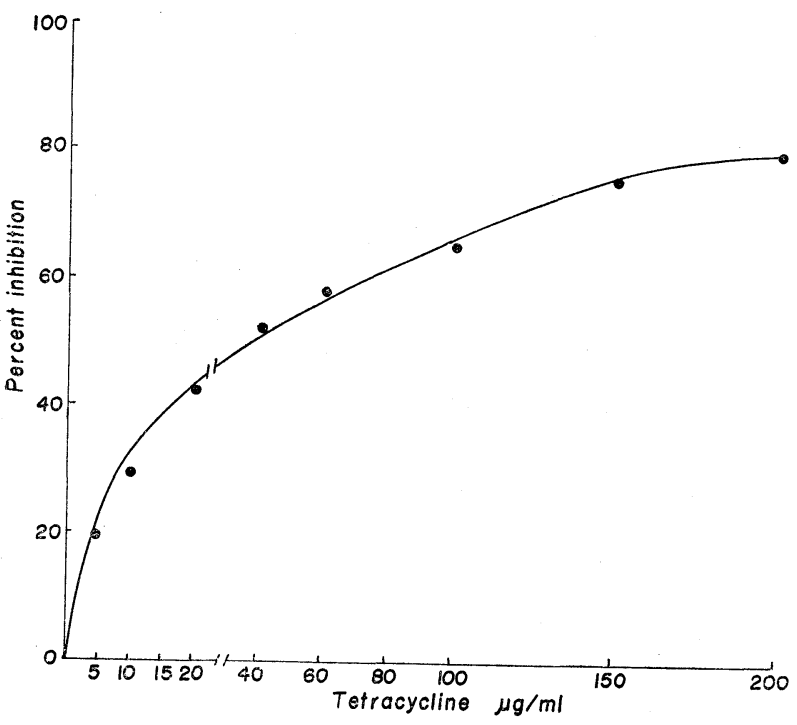

nonpreincubated mixture contains endogenous mRNA sensitive to RNAse action. Protein synthesis in this systems is not dependent on the presence of DNA. After preincubation of the $\mathrm{S} 30$ fraction to destroy endogenous mRNA, synthesis of proteins was lowered to $10 \%$ of the maximal value observed with the nonpreincubated fraction. Dialyzed S30 fraction without preincubation was used for studies of the effect of tetracycline on protein synthesis in the tetracycline-producing strain. Fig. 9 shows per cent inhibition of protein synthesis obtained at different levels of tetracycline.

The results suggest that the protein-synthesizing system of S.aureofaciens is much more resistant to the antibiotic than a similar system isolated from sensitive bacteria. It has been reported in experiments with $E$. coli $\left.{ }^{17}\right)$ that $10 \mu \mathrm{g} / \mathrm{ml}$ of tetracycline causes $80 \%$ inhibition of poly U-directed synthesis of polyphenylalanine. Comparable inhibitory effect was observed in the present experiments with S.aureofaciens at drug concentration of at least $200 \mu \mathrm{g} / \mathrm{ml}$. There is a lack of information about the localization of resistance to tetracycline in the in vitro protein synthesizing systems. Recently, CRAven et al. ${ }^{33)}$ isolated a tetracycline-resistant mutant of E. coli containing ribosomes resistant in vitro. Resistance to the antibiotic can be abolished or decreased by salt washing. It is not known whether this resistance is located in a ribosomal protein or in the initiation factors. More detailed informations about this problem are under examination.

The results suggest that intracellular accumulation of tetracycline during the growth of S.aureofaciens could lead to blockage of protein synthesis by the producing cells.

\section{Acknowledgement}

This work was supported in part by an International Atomic Energy Agency Grant No. 845/Rb.

\section{References}

1) Johnson, E. J. \& A.R. Colmer : The relation of magnesium ion to the inhibition of the respiration of Azotobacter vinelandii by chlortetracycline, tetracycline, and 2, 4-dichlorrophenoxyacetic acid. Antibiot. Chemoth. $7: 521 \sim 526,1957$

2) Snell, J. F. \& L. Cheng: Studies on modes of action of tetracyclines. II. Develop. Ind. Microbiol. $2: 107 \sim 132,1961$

3) Bernheim, F.: The effect of certain antibiotics on the formation of an adaptive enzyme in a strain of Pseudomonas aeruginosa. J.Pharmacol. Exptl. Therap. $110: 115 \sim 119,1954$ 
4) Creaser, E. H.: The induced (adaptive) biosynthesis of $\beta$-galactosidase in Staphylococcus aureus. J. Gen. Microbiol. $12: 288 \sim 297,1955$

5) SAz, A.K; L.W. Brownell \& R.B. SuIe: Aureomycin resistant cell-free nitroreductase from aureomycin-resistant Escherichia coli. J. Bact. $71: 421 \sim 424,1956$

6) Melnykovych, G. \& K. R. Johansson: Effects of chlortetracycline on the stability of arginine decarboxylase in Escherichia coli. J. Bact. $77: 638 \sim 641,1959$

7) Rokos, J.; M. Burger \& P. Procházka : Effects of calcium ions on the inhibition of hydrolases by chlortetracycline. Nature $181: 1201,1958$

8) Rokos, J.; M. Burger \& P. Procházka : Effect of chlortetracycline on the activity of $\alpha$-amylases. Antibiotiki $4: 3 \sim 7,1959$

9) Rokos, J.; P. Málek, M. Burger, P.Prochízka \& J. Kold : The effect of divalent metals on the inhibition of pancreatic lipase by chlortetracycline. Antibiot. \& Chemoth. 9: 600 608, 1959

10) Alexander, B.: Effect of chlortetracycline on vitamin $B_{6}$ and amino acid decarboxylase in bacteria from the alimentary tract of the chick. Appl. Microbiol. $8: 69 \sim 72,1960$

11) Fuwa, I. \& J. OKudA : Inhibitory action of tetracyclines on polynucleotide phosphorylase. J. Biochem. $59: 95 \sim 103,1966$

12) Mikolajcik, E. M.: Antibiotic influence on arginine desimidase activity by Streptococcus lactis. J. Dairy Sci. $48: 1445 \sim 1448,1966$

13) DeVries, H. \& A.M.Kroon: On the effect of chloramphenicol and oxytetracycline on the biogenesis of mammalian mitochondria. Biochim. Biophys. Acta $204: 531 \sim 541,1970$

14) Gurgo, C.; D. Apirion \& D. Schlessinger : Polyribosome metabolism in Escherichia coli treated with chloramphenicol, neomycin, spectinomycin or tetracycline. J. Mol. Biol. $45: 205 \sim 220,1969$

15) Cundiffe, E.: Polyribosomes and ribosomal sub-units of bacterial protoplasts. Biochem. Biophys. Res. Commun. 33 : 247 259, 1968

16) Hienowski, M.: Inhibition of protein synthesis by chlortetracycline in the E. coli in vitro system. Proc. Natl. Acad. Sci. U.S. $53: 594 \sim 599,1965$

17) Suarez, G. \& D. Nathans: Inhibition of aminoacyl-sRNA binding to ribosomes by tetracycline. Biochem. Biophys. Res. Commun. 18:743 750, 1965

18) Gottesman, M.E.: Reaction of ribosome-bound peptidyl transfer ribonucleic acid with aminoacyl transfer ribonucleic acid or puromycin. J. Biol. Chem. 242:5564 5571, 1967

19) SARKAR, S. \& R. E. THACH : Inhibition of formylmethionyltransfer RNA binding to ribosomes by tetracycline. Proc. Natl. Acad. Sci. U.S. $60: 1479 \sim 1486,1968$

20) KURIKI, Y. \& A. KAJI : Factor-and guanosine 5'-triphosphate-dependent release of deacylated transfer RNA from 70S ribosomes. Proc. Nat1. Acad. Sci. U.S. $61: 1399 \sim 1405,1968$

21) Ishitsuka, H. \& A. KAJI : Release of tRNA from ribosomes by a factor other than $G$ factor. Proc. Natl. Acad. Sci. U.S. $66: 168 \sim 173,1970$

22) Hošx̌́́Leк, Z.: Relationship between the carbohydrate metabolism of Streptomyces aureofaciens and the biosynthesis of chlortetracycline. Fol. Microbiol. $9: 78 \sim 88,1964$

23) Mikultk, K.; N. Quyen, M. Blumauerová \& Z. VaněK : Binding of aureovocin to ribosomes of Streptomyces aureofaciens B-96. FEBS Lett. 5 : 131 134, 1969

24) Matthaei, J.H. \& M. W. Nirenberg : Characteristics and stabilisation of DNase-sensitive protein synthesis in E.coli extracts. Proc. Natl. Acad. Sci. U.S. $47: 1580 \sim 1588,1961$

25) Traub, P. \& M. Nomura: Structure and function of Escherichia coli ribosomes. I. Partial fractionation of the functionally active ribosomal proteins and reconstitution of artificial subribosomal particles. J. Mol. Biol. $34: 575 \sim 593,1968$

26) Gesteland, R.F. \& T. Staehelin : Electrophoretic analysis of proteins from normal and cesium chloride-treated Escherichia coli ribosomes. J. Mol. Biol. $24: 149 \sim 155,1967$

27) Mikulfk, K.; M. Blumauerová, Z. VANĚK \& J. Ludvik : Characterization of ribosomes of a strain of Streptomyces aureofaciens producing chlortetracycline. Fol. Microbiol. $16: 24 \sim 30,1971$

28) DAy, L.E.: Tetracycline inhibition of cell-free protein synthesis. I. Binding of tetracycline to components of the system. J. Bact. $91: 1917 \sim 1923,1966$

29) Connamacher, R.H. \& H. G. Mandel : Studies on the intracellular localization of tetracycline in bacteria. Biochim. Biophys. Acta $166: 475 \sim 486,1968$

30) Last, J.A.: Studies on the binding of tetracycline to ribosomes. Biochim. Biophys. Acta 195: $506 \sim 514,1969$

31) Maxwell, I. H.: Studies of the binding of tetracycline to ribosomes in vitro. Mol. Pharmacol. $4: 25 \sim 37,1968$

32) Hošť́llék, Z.; M. Tintěrová, V. Jechoví, M. Blumaueroví, J. SuchÝ \& Z. VaněK : Regulation of biosynthesis of secondary metabolites. I. Biosynthesis of chlortetracycline and tricarboxylic acid cycle activity. Biotechnol. Bioeng. $9: 539 \sim 548,1969$

33) Craven, G. R.; R. Gavin \& T. Fanning : The transfer RNA binding site of the $30 \mathrm{~S}$ ribosome and the site of tetracycline inhibition. Cold Spring Harbor Symp. Quant. Biol. 34 : 129 137, 1969 